Omni-Akuatika, 14 (2) : 116-122, 2018
ISSN: 1858-3873 print / 2476-9347 online
Research Article
journal homepage: http://ojs.omniaquatika.net

\title{
Effects of Leads Pb on Gill Microanatomy Structure of Hard-Lipped Barb Fish Osteochilus hasselti
}

\author{
Asrul Sahri Siregar ${ }^{{ }^{\star}}$, Sofi Alfiyah ${ }^{1}$, Norman Arie Prayogo ${ }^{1}$, Isdy Sulistyo ${ }^{1}$ \\ ${ }^{1}$ Fishery and Marine Faculty, Jenderal Soedirman University, Purwokerto, Indonesia \\ *Corresponding author: asrul_sir@yahoo.com
}

\begin{abstract}
As a harmful and non-degradable heavy metal, lead $(\mathrm{Pb})$ is also toxic to aquatic organisms. This metal damages tissue and sensitive organs such as gills. A study dealt with the effect of $\mathrm{Pb}$ concentration and contact time on gill microanatomy structure of hard-lipped barb fish (Osteochilus hasselti). An experimental method was applied during study with Completely Randomized Design to test 4 concentrations of $\mathrm{Pb}$, i.e $0 \mathrm{mg} / \mathrm{L}\left(P_{0}\right), 8.93 \mathrm{mg} / \mathrm{L}\left(P_{1}\right), 17.86 \mathrm{mg} / \mathrm{L}\left(P_{2}\right)$ and $26.80 \mathrm{mg} / \mathrm{L}\left(P_{3}\right)$, in quadruplicates. The gills were removed, and fixed in Bouin solution, from fish sampled twice in a month. The gills were subsequently processed in classical histology to obtain gill microanatomy structure damage data. The data were established from Pantung method, which were then analyzed with One-way ANOVA. The results showed that $\mathrm{Pb}$ damaged gills, mildly to severely, in form of oedema, hyperplatia, lamella fusions, and necrosis. Concentration levels and contact time affected microanatomy structure damage of gills. The increasing concentration levels and length of contact time did not gravely increase in damage.
\end{abstract}

Keyword: lead $(P b)$, microanatomy, gills, hardlipped-barb

\section{Introduction}

Heavy metal represents, including leads $(\mathrm{Pb})$, toxic pollutant affecting some biological and ecological treats (Dahuri et al., 1996). Uncontrolled accumulating heavy metals could be dispersed in environmental. Palar (1994) stated that heavy metals could be stored in organisms in long term, and consequently imperil them. Leads are non-biodegrable and accumulated and sinked to bottom either with organic and inorganic matters (Rochyatun and Rozak, 2007). High concentration of leads causes some biota mortalities (Hutagalung, 1997). The author also revealed that the increase of leads, previously needed to metabolism, became toxic to organisms themselves.

Leads enter to organisms through food chains, gills, or skin difusion, and consequently bio-accumulate in tissues and damage some organs of an organism (Palar, 1994), e.g gills, instentine, liver, and kidney (Darmono, 2001). leads in gills of some aquatic orgnisms cause stress, by consquence, disturb $\mathrm{O}_{2}$ diffusion into gills. This could affect gill damages (Sandi, 1994).

Gills actually are very sensitive organ to metal toxic, since they directly expose to environmental toxic matters. Gills could also be able to regulate between pressure in water and internal liquid of organism (Wong, 2000; Moyes, 2006 in Tasykal, 2015).

Some previous researches dealing with the effects of heavy metals on gill microanatomy structure had been reported. In some intances, Mulyani et al., (2014) noted that, in tilapia, lead-acetate $\left[\mathrm{Pb}\left(\mathrm{CH}_{3} \mathrm{OO}\right)_{2}\right]$ in a concentration of $324.3 \mathrm{ppm}$, as LC50-96, caused some damages of gill structure. Gills presented lamellae fusion (gravest damage), oedeme, hypeplatia, epithelial lifting, necroses (mildest damage). These damages were appeared due to mucose on lamellae binded leads, which in turn avoided gas and ionic changes.

Study on lead effects to gill structure in hard-lipped barb had never been reported yet. The fish, belonging to Cyprinid, represents an important economic fish in Banyumas district, since people of the district culture this fish for long time ago. This fish lives in vast region, tolerates easily insuitable aquatic conditions, and could be certainly reared under laboratory circumstances (Djiwakusumah, 1980, Prayogo et al., 2016). A new study, in this fish 
therefor, was necessary to be established dealing with the effects of leads on gill microanatomy structure.

\section{Materials and Methods}

This study was conducted, between March-July 2017, for toxicity test in Experimental Station of Biology Faculty of Unsoed. Microanatomical treatments and observations were run in Research Laboratory of Medicine Faculty of Unsoed.

An experimenntal method was applied during the study in Completely Radomized Design to test four treatments, i.e. $0 \%, 20 \%$, $40 \%$ dan $60 \%$ of LC50-96 concentration. Sublethal test was run for 14 days to examine four treatments, i.e. $0 \mathrm{mg} / \mathrm{L}$ (control), $8.93(\mathrm{P} 1)$, $17.86 \mathrm{mg} / \mathrm{L}$ (P2), and $26.80 \mathrm{mg} / \mathrm{L}$ (P3). All treatments were populated with 15 individual fish measuring $10-13 \mathrm{~cm}$ in total length.

Gills were removed, of 1 st and 2nd weeks of post-treatment, from 3 fish samples of each treatment. During aclimation, an aeration system was applied over all aquaria, and fish fed twice a day ad-libitum on pellets. Leads for this study were in form of $\mathrm{Pb}\left(\mathrm{NO}_{3}\right)_{2}$ being solved in $0.01 \mathrm{~N}$ nitric acid and aquadest according to formula :

\section{$v_{1} \times n_{1}=v_{2} \times n_{2}$}

\section{Where :}

$\mathrm{v} 1=$ lead volume needed $(\mathrm{L})$

$\mathrm{n}_{1}=$ stock solution concentration of lead

(mg/L)

$\mathrm{v}_{2}=$ media volume $(\mathrm{L})$

n2= each lead concentration $(\mathrm{mg} / \mathrm{L})$

\section{Histological section procedures of gill tissues}

Microanatomical sections of gills were prepared according to Sholehah (2015) with paraffin and hematoxylin and eosin techniques. The procedures were followed:

1) Fixation of tissues in Bouin solution.

2) Dehidration in alcohol of $70 \%, 80 \%, 90 \%$, Absolute I, and Absolute II, successively, for 60'.

3) Clearing in alcohol-xylene (1:1 then 1:3 vv), xylene I, and xylene II, successively, for 30 .
4) Gradual infiltration in solutions of xylene:paraffin $(1: 1 \mathrm{vv})$ for 25 , and then in pure paraffin $2 \times 60$.

5) Embedding in paraffin block above a heater in $70^{\circ} \mathrm{C}$. Base mold of $4 \times 3 \times 2 \mathrm{~cm}$ dimension was filled with liquid paraffin, then samples were placed vertically in the mold, and a previously labelled holder was then covered. Paraffin should be let to harden. Sectioning in microtome was set as $5 \mu \mathrm{m}$ of thickness. Sections were then moved to water bath to facilitate attachment on object glasses which were labelled.

6) Deparaffinised by dipping the object glasses in xylene I and II for 15' each.

7) Rehydration (removing xylene) by dipping them in $100 \%, 90 \%, 80 \%$, and $70 \%$ alcohol for 15' each. The object glasses were consequently in aquadest for $15^{\prime}$.

8) Staining in haematoxylin for 10' and washing in tap water for 2' and in acid alcohol for 5", and in aquadest for 2'. Staining in eosin for 10'.

9) Dehydration in $70 \%, 80 \%, 90 \%$ and $100 \%$ for 30 '.

10) Clearing by dipping in xylene for 10 '.

11) Mounting and covering with entellan and coverglass over object glasses.

12) Observation under light microscope.

Data

Microanatomical damages of gills were calculated with modified Pantung method (Pantung, 2008 in Rennika et al., 2013) i.e. semiquantitative scoring method by analyzing histopathological surface according to detail analyses as in Tabel 1.

Data analyses

Data, as forme of scores, were One Way ANOVA tested for concentration levels and expose duration to examine their effects. For further analyses, Least Difference Test was applied to determine which treatment should be pointed. Comparative descriptive analyses were applied on microanatomical structure damages of gills i.e. oedema, hyperplatia, fusion, dan necrosis of lamellae. 
Tabel 1. Scoring according to Pantung method applied to gill microanatomical changes (Rennika et al., 2013)

\begin{tabular}{|c|c|c|c|c|c|}
\hline Scoring & Parameters & Normal & Mild & Middle & Severe \\
\hline 0 & $\begin{array}{c}\text { Oedema } \\
\text { Lamellae (OL) }\end{array}$ & No at all & $\begin{array}{l}\text { Less than } 30 \% \\
\text { of viewing }\end{array}$ & $\begin{array}{c}30 \%-70 \% \text { of } \\
\text { viewing }\end{array}$ & $\begin{array}{c}\text { More than } 70 \% \text { of } \\
\text { viewing }\end{array}$ \\
\hline 1 & $\begin{array}{c}\text { Hyperplatia } \\
\text { Lamellae (HL) }\end{array}$ & No at all & $\begin{array}{l}\text { Less than } 30 \% \\
\text { of viewing }\end{array}$ & $\begin{array}{c}30 \%-70 \% \text { of } \\
\text { viewing }\end{array}$ & $\begin{array}{c}\text { More than } 70 \% \text { of } \\
\text { viewing }\end{array}$ \\
\hline 2 & $\begin{array}{c}\text { Fusion } \\
\text { Lamellae (FL) }\end{array}$ & No at all & $\begin{array}{l}\text { Less than } 30 \% \\
\text { of viewing }\end{array}$ & $\begin{array}{c}30 \%-70 \% \text { of } \\
\text { viewing }\end{array}$ & $\begin{array}{c}\text { More than } 70 \% \text { of } \\
\text { viewing }\end{array}$ \\
\hline 3 & $\begin{array}{c}\text { Necrosis } \\
\text { Lamellae (NL) }\end{array}$ & No at all & $\begin{array}{l}\text { Less than } 30 \% \\
\text { of viewing }\end{array}$ & $\begin{array}{c}30 \%-70 \% \text { of } \\
\text { viewing }\end{array}$ & $\begin{array}{c}\text { More than } 70 \% \text { of } \\
\text { viewing }\end{array}$ \\
\hline
\end{tabular}

\section{Results and Discussion}

\section{Gill microanatomical based on Lead concentrations}

Microanatomical structure damages of gills presented various levels according to treatments (Table 2). These damages represented given data were observed under microscope (10x25 magnitude).

Table 2. Gill microanatomy of hard-lipped barb (Osteochilus hasselti) from $1^{\text {st }}$ and $2^{\text {nd }}$ week samples.

\begin{tabular}{|c|c|c|c|c|c|c|c|c|c|}
\hline \multirow{3}{*}{ Treatments } & \multirow{3}{*}{ Replicates } & \multicolumn{8}{|c|}{ Microanatomical Structure Damages } \\
\hline & & \multicolumn{2}{|c|}{ OL } & \multicolumn{2}{|c|}{$\mathrm{HL}$} & \multicolumn{2}{|c|}{$\mathrm{FL}$} & \multicolumn{2}{|c|}{ NL } \\
\hline & & W1 & W2 & W1 & W2 & W1 & W2 & W1 & W2 \\
\hline & C1 & normal & normal & normal & normal & normal & normal & normal & normal \\
\hline \multirow{3}{*}{ Control } & C2 & normal & normal & normal & normal & normal & normal & normal & normal \\
\hline & C3 & normal & normal & normal & normal & normal & normal & normal & normal \\
\hline & P1.1 & normal & normal & mild & mild & middle & middle & middle & middle \\
\hline \multirow[t]{3}{*}{ P1 } & P1.2 & normal & normal & mild & normal & severe & mild & mild & severe \\
\hline & P1.3 & normal & normal & mild & normal & middle & middle & middle & middle \\
\hline & P2.1 & mild & normal & mild & mild & middle & middle & middle & middle \\
\hline \multirow[t]{3}{*}{ P2 } & P2.2 & mild & mild & middle & mild & mild & middle & mild & middle \\
\hline & P2.3 & normal & mild & mild & mild & middle & middle & middle & middle \\
\hline & P3.1 & normal & normal & mild & mild & middle & middle & middle & middle \\
\hline \multirow[t]{2}{*}{ P3 } & P3.2 & normal & mild & normal & mild & middle & mild & middle & middle \\
\hline & P3.3 & normal & mild & normal & mild & mild & mild & evere & middle \\
\hline
\end{tabular}

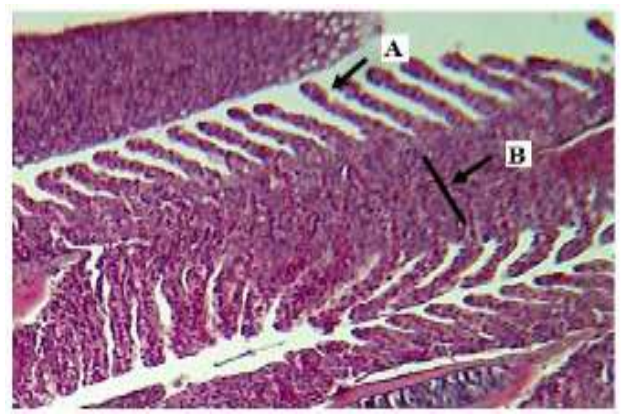

Figure 1. Gill microanatomical features in hard-lipped barb (Osteochilus hasselti) from Control (10x25 magnitude). A. Secondaire Lamellae; B. Primary Lamellae.

Figure 1 presented entire gill structure with intact primary and scondary lamellae. These results were in line with the report from Susanah (2011) i.e. normal gill of fish was still complete and either primary and secondary lamellae were intact. 


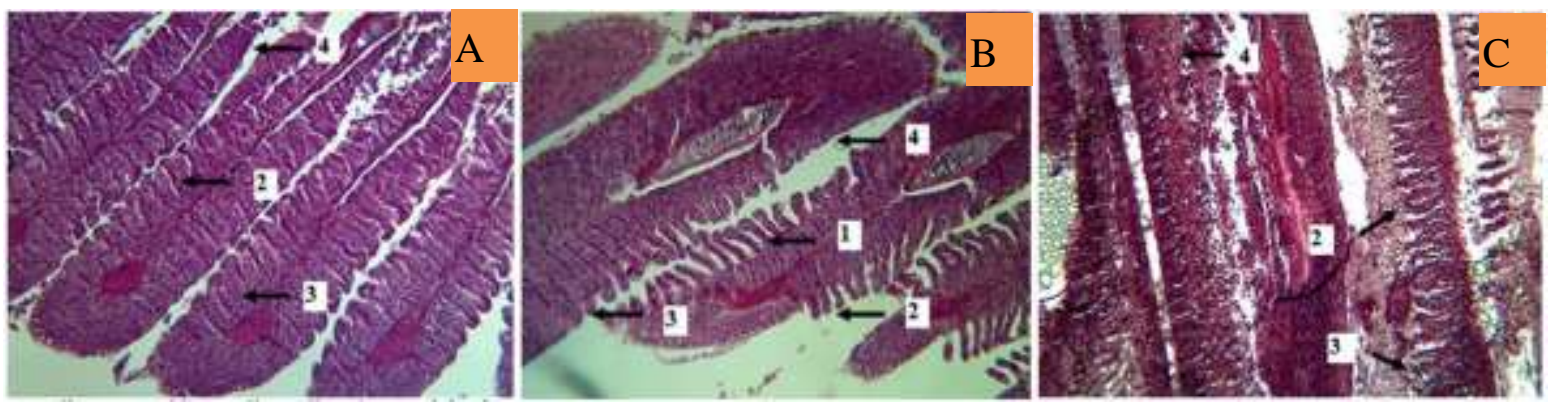

Figure 2. Gill microanatomical features in hard-lipped barb (Osteochilus hasselti) of $1^{\text {st }}$ week. A. Treatment $8.93 \mathrm{mg} / \mathrm{L}$ (P1); B. Treatment $17.86 \mathrm{mg} / \mathrm{L}$ (P2); C. Treatment $26.80 \mathrm{mg} / \mathrm{L}$ (P3); 1. Oedema; 2. Hyperplatia, 3. Fusion; 4. Necrosis Lamellae.
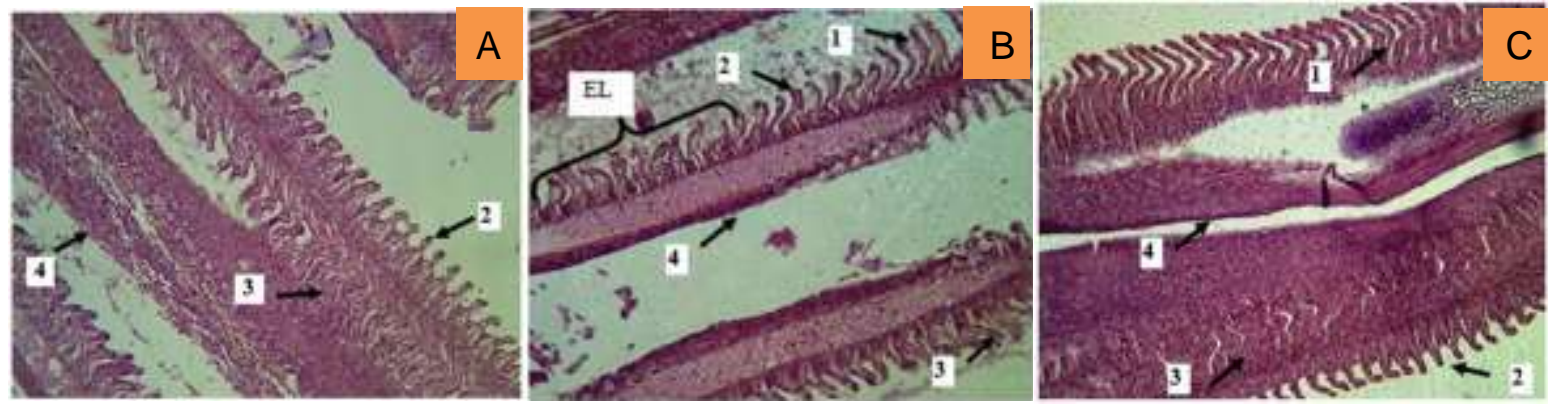

Figure 3. Gill microanatomical features in hard-lipped barb (Osteochilus hasselti) of $2^{\text {nd }}$ week. A. Treatment $8.93 \mathrm{mg} / \mathrm{L}$ (P1); B. Treatment $17.86 \mathrm{mg} / \mathrm{L}$ (P2); C. Treatment $26.80 \mathrm{mg} / \mathrm{L}$ (P3); 1. Oedema; 2. Hyperplatia, 3. Fusion; 4. Necrosis Lamellae.

Gill lamellae changes were observed as gill microanatomical structure as a result of lead exposure. These changes were possibly due to toxic effects of leads. Chavan and Muley (2014) reported that gill microanatomical changes were related to given toxical aspects. Or, these changes responded adaptively against heavy metal intake and gill permeability increase.

Lamellae damages could be oedema, hyperplatia, fusion, and necrosis (figure 2 dan $3)$. Oedema represented over swollen cells causing lamellae epithel cells displaced from underneath tissues. Hyperplatia was tissues forming due to cell exessive multiplication. Fusion was marked with mucous cell increase on lamellae base to do so secondary lamellae unified. Necrosis meant that secondary lamellae structure disappeared and fillaments damaged.

Damage levels varied from mild to severe (Table 2). Necrosis were worst following with fusion, hyperplatia, and oedema. Rennika et al., (2013) stated that gill damage leaded to $\mathrm{O}_{2}$ consumption difference in higher lead concentration, and the ability of blood to bind the $\mathrm{O}_{2}$. Lead toxic affected disturbance of respiration and metabolism in fish. Leads raised the activity of gill mucoses, in consequently, gills were covered with thick mucose containing leads, and respiration and metabolism were disturbed. 


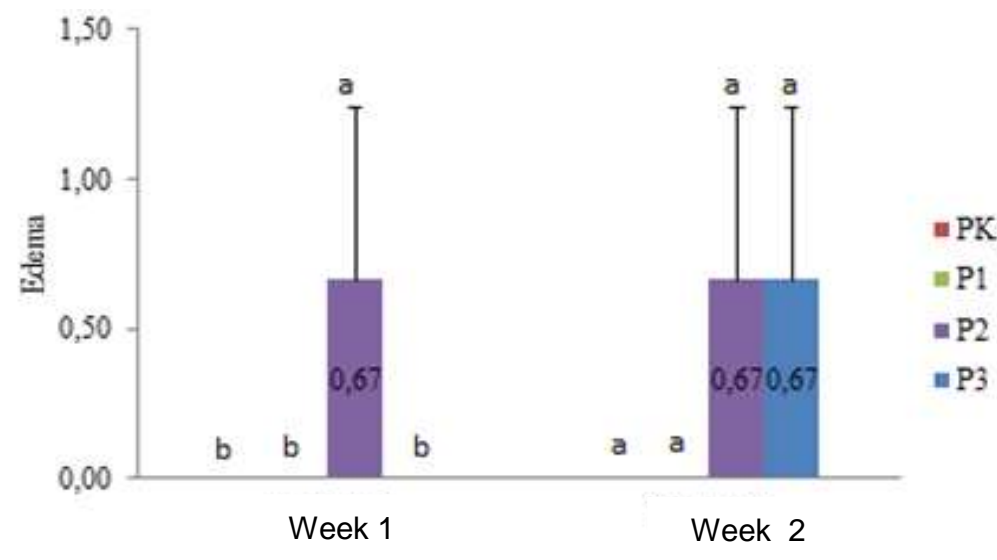

PK: $0 \mathrm{mgL}, \mathrm{P1}: 8,93 \mathrm{mgL}, \mathrm{P2}: 17,86 \mathrm{mgL}, \mathrm{P3}: 26,80 \mathrm{mg} \mathrm{L}$

Figure 3. Average diagrams $( \pm S D)$ of oedema in hard-lipped barb (Osteochilus hasselti) frrom $1^{\text {st }}$ and $2^{\text {nd }}$ week of lead exposure.

Time of lead exposure affected extended oedema in P3, however in P2, oedema remained stable, and in $\mathrm{P} 1$ did not affect (Figure 3). Low oedema might be due to that leads rather affected on hyperplatia, fusion, and necrosis. This was in accordance with Rennika et al., (2013), i.e. $\mathrm{PbCl}_{2}$ concentration impaired either hyperplatia, fusion, or necrosis. One-way ANOVA of oedema from $1^{\text {st }}$ week presented significantly different $(<0.05)$, meaning that lead concentrations affected on gill microanatomical structure of this fish. However, in $2^{\text {nd }}$ week, these concentrations did not affect. Oedema in gill could be caused of direct contact of leads with epithel cells, and due to lead deposition in cytoplasm raising irritating.

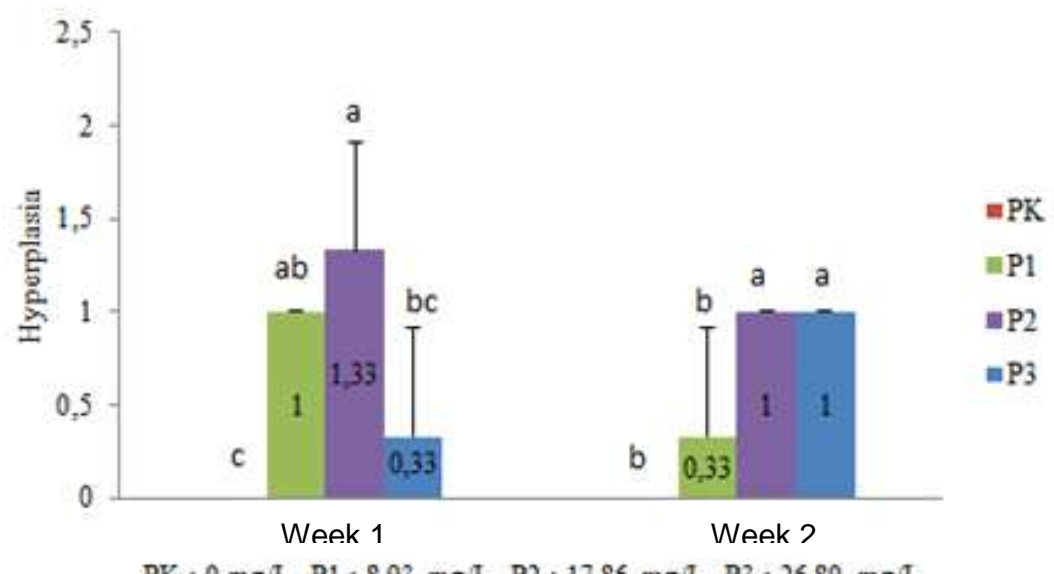

Figure 4. Average diagram $( \pm S D)$ of hyperplatia in hard-lipped barb (Osteochilus hasselti) of $1^{\text {st }}$ and $2^{\text {nd }}$ week of lead exposure.

Time exposure of leads affected extended hyperplatia in P3, however, hyperplatia in $\mathrm{P} 1$ and $\mathrm{P} 2$ reduced (Figure 4). Reducing in hyperplatia could be caused by extended hyperplatia would lead to lamella fusion. This was showed in P1 and P2 in parallel with lamella fusion increase from same treatments. One-way ANOVA of hyperplatia from 1 st and 2 nd week showed significantly different $(<0.05)$, meaning that lead concentrations affected on microanatomical structure damages of gills. Hyperplatia could be a consequence of tissue irritation due to pollutants, and normally, followed increasing of number mucose cells in lamellae base. The pollutants could be in forme of nitrate leads (Rennika et al., 2013). Hyperplatia could therefore arise when the fish populated the environment containing permanently chemical subtances. 


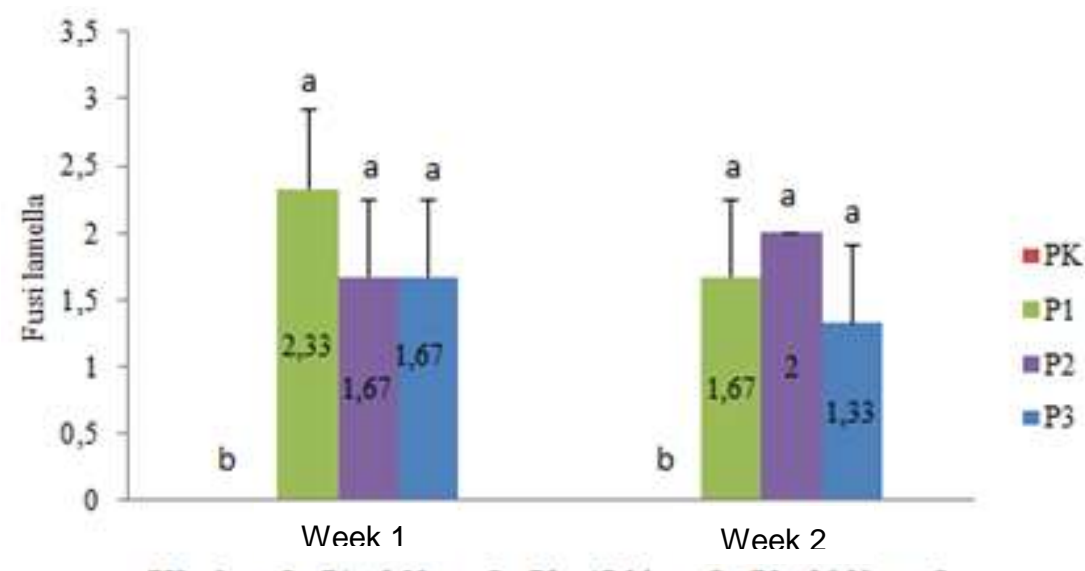

PK : $0 \mathrm{mg} / \mathrm{L}, \mathrm{P1}: 8,93 \mathrm{mg} / \mathrm{L}, \mathrm{P} 2: 17,86 \mathrm{mg}$, P3 : $26,80 \mathrm{mg} / \mathrm{L}$

Figure 5. Average diagram ( \pm SD) of lamella fusion of hard-lipped barb (Osteochilus hasselti) from $1^{\text {st }}$ and $2^{\text {nd }}$ week of lead exposure.

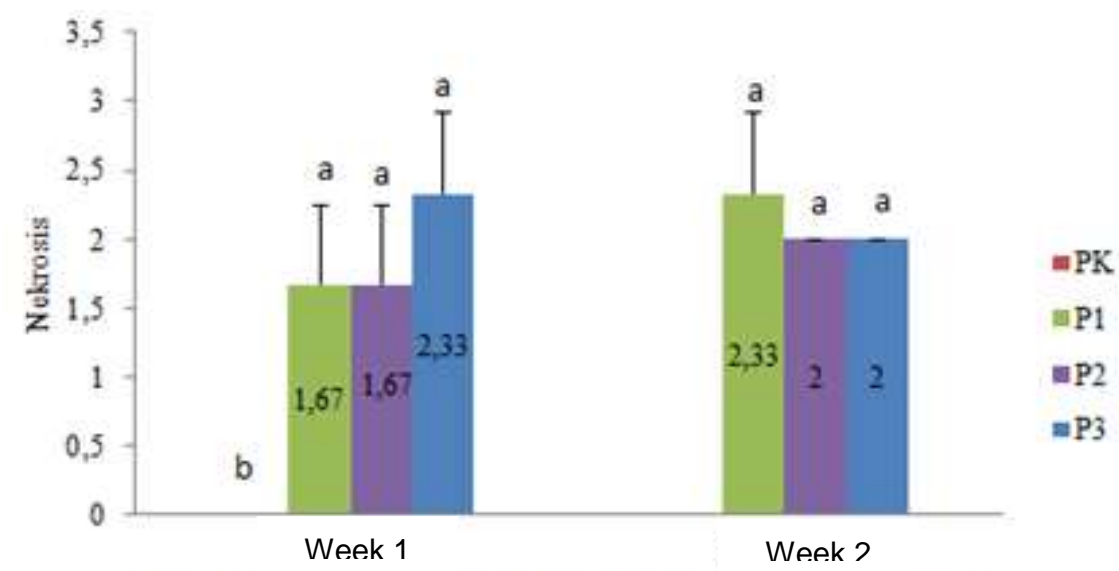

PK : $0 \mathrm{mg} / \mathrm{L}, \mathrm{P} 1$ : $8,93 \mathrm{mg} / \mathrm{L}, \mathrm{P} 2: 17,86 \mathrm{mg} / \mathrm{L}, \mathrm{P} 3: 26,80 \mathrm{mg} / \mathrm{L}$

Figure 6. Average diagram $( \pm S D)$ of necrosis gills in hard-lipped barb (Osteochilus hasselti) from $1^{\text {st }}$ and $2^{\text {nd }}$ week of lead exposure.

Time of exposure affected lamella fusion extends in P2, however, it decreased in P1 and P3 (Figure 5). This reduction could be caused by decreasing of lead toxic level. Oneway ANOVA of lamella fusion in 1st and 2nd showed significantly different $(<0.05)$, meaningly that exposure of lead concentrations affected microanatomical structure damages of gills. Lamella fusion could be due to contact of gills with leads. Gills excreted extended mucoses to cover them against leads, unfortunately, the mucoses would extensively mask lamella gills resulting in disturbance of $\mathrm{O}_{2}-\mathrm{CO}_{2}$ exchange. Sukarni et al., (2012) in Sholehah (2015) revealed that extensive mucoses represented a response of the glands to protect gills against leads, however mucose secretion could be over.

Time of exposure increased significantly (one-way ANOVA, <0.05) necrosis in P1 and
$\mathrm{P} 2$ from $1^{\text {st }}$ and $2^{\text {nd }}$ week, however in P3, necrosis decreased (Figure 6). Decrease in necrosis, in P3, could be due to reducing in adaptive response against lead exposure. In milkfish Chanos chanos, Alifia (2013) reported that higher lead level caused lower adaptive response. Other report by Anderson, (1995) in Susanah, (2011) revealed that necrosis could occur as a result of strange substance intake, i.e. leads. Leads set off the cells could not succeed metabolism, resulting in energertic formation was avoided.

\section{Conclusion}

1. Lead concentration affected microanatomical structure of gills in hard-lipped barb (Osteochilus hasselti) showing some damages, e.g. oedema, hyperplatia, fusion, 
and necrosis lamellae. Incerase damages were in parallel with increase lead concentrations.

2. Time of exposure of leads upset microanatomical structure damages of gills in hard-lipped barb (Osteochilus hasselti), with various damage levels according to treatments.

Lowest concentration of $8.93 \mathrm{mg} / \mathrm{L}$ remained trigger gill defects, this leaded to establish various doses of leads that still suitable for fish.

\section{Refferences}

Chavan, V.R,. Muley, D.V. 2014. Effect of Heavy Metals on Liver and Gill of Fish Cirrhinus mrigala. International Journal of Current Microbiology and Aplplied Sciences. 3(5) : 277-288.

Darmono. 2001. Environment and Pollution : Relationship with Toxicology of Metal Compounds. UI Press. Jakarta.

Hutagalung, H. P. 1997. Methods Analysis of Sea Water, Sediment and Biota. Center for Oceanographic Research and Development. Jakarta.

Mulyani, F.A.M., Widiyaningrum, P.,Utami N.R. 2014. Toxicity and Changing Test of Microanatomical Structure of Gill of Nila Larasati Fish (Oreochromis nilloticus Var.) Exposed to Acetate Lead. Jurnal MIPA. 37(1) : 1-6.

Palar, H. 1994. Heavy Metal Pollution and Toxicology. Rineka Cipta. Jakarta.

Prayogo, N. A., Hidayati, A., Siregar, A. S., Yunasfi. 2016. Test of Lethal Toxicity and Subletal of Heavy Metals of Mercury on Nile Fish (Osteochilus hasseltii). Omni Akuatika, 12 (1) : 8694.
Rennika, Aunurohim., Nurlita A. 2013. Concentration and Length of Exposure of Organic and Inorganic Compounds on the Mujair Fish Gill Network (Oreochromis mossambicus) in Sub Lethal Condition. Jurnal Sains dan Seni Pomits. 2(2) : 2337-3520.

Rochyatun, E., Rozak, A. 2007. Monitoring of heavy metal content in sediment in the waters of Jakarta Bay. Makara sains. 11(1): 28-36.

Sandi, E. 1994. The Effect of Suspended Solids on Death and Nungge Band Growth Rate (Chanos chanos forskal) on Test Media. Essay. Diponegoro University. Semarang.

Sholehah, T. W. 2015. Test of Lethal Toxicity and Subletal Mercury $(\mathrm{Hg})$ against Damage to Gill Fish Nilem (Osteochilus hasselti). Essays. Faculty of Fisheries and Marine Science. General Soedirman University.Purwokerto.

Susanah, U.A. 2011. Structure of Microfatanomy of Gill of Milkfish in Tambak Area of Tugurejo Subdistrict of Tugu Subdistrict, Semarang. Essays. Semarang State University.Semarang.

Tasykal, A.R. 2015. Histopathology of Organ Organic Liver and Gill of Milkfish Contaminated Chicken (Pb) In Labakkang Sub-district of Pangkep Regency. Essay. Veterinary Studies Program, Hasanuddin University.Makassar.

Wong, Chris K., Wong, M.H. 2000. Morphological and Biochemical Changes in the Gills of Tilapia (Oreochromis mossambicus) to Ambient Cadmium Exposure. Aquatic Toxicology. 48 : 517-527. 